JOURNAL

OF TOURISM

AND ECONOMIC
Journal of Tourism and Economic Vol.3, No.2, 2020, Page 77-96

ISSN: 2622-4631 (print), ISSN: 2622-495X (online)

Email:jurnalapi@gmail.com

Website: http://jurnal.stieparapi.ac.id/index.php/JTEC

DOI: https://doi.org/10.36594/jtec.v3i2.100

\title{
SARANA TRANSPORTASI SEBAGAI DAYA TARIK WISATA: KAJIAN PERSEPSI WISATAWAN BERKUNJUNG KE KEPULAUAN SERIBU STUDI KASUS: KAPAL KM SABUK NUSANTARA 66
}

\author{
Kadek Wiweka \\ École Doctorale Sociétés, Temps, Territoires (EDSTT) Tourisme, Université Angers, France \\ kadek.wiweka@etud.univ-angers.fr , wiweka.kadek88@gmail.com \\ Suci Sandi Wachyuni \\ Kajian Pariwisata Sekolah Pascasarjana Universitas Gadjah Mada dan Politeknik Sahid \\ suci.sandi.wachyuni@mail.ugm.ac.id, sucisandi91@gmail.com
}

Putu Pramania Adnyana

Faculty of Humanities, University of Indonesia, Indonesia putu.pramania@gmail.com

Anjani Nurul Safitri

Politeknik Sahid, Indonesia

\begin{abstract}
Historically until now, accessibility, especially transportation, has played an important role in tourism development. This study aims to identify tourists' perceptions of tourist transportation (KM Sabuk Nusantara 66) as an attraction for tourists visiting the Kepulauan Seribu from the port of Sunda Kelapa. This study adopted a qualitative approach to triangulation data collection techniques. The research location was carried out at Sunda Kelapa Port, involving the ship captain (PT. Pelni) and the KSOP Sunda Kelapa Port staff. The number of samples determined using a purposive sampling technique. Meanwhile, tourists are determined by the judgmental sampling technique. This data collection was carried out for three months, from May to July 2018. This study found that the KM Sabuk Nusantara 66 Ship's feasibility is following tourists' perceptions based on 10 indicators of transportation factors to support tourism. This research can be used to suggest ship operators and destination managers' development improve service quality continuously. This study has limitations on the sample of transportation companies involved. Future research is expected to reach a wider sample or even reach other transportation types, such as tourist trains, tour buses, or even air transportation.
\end{abstract}

Keywords : Transportation, Tourist Attractions, Tourist Perception, Kepulauan Seribu 


\begin{abstract}
ABSTRAK
Secara historis dan hingga kini, aksesibilitas, khususnya transportasi telah memainkan peran penting dalam perkembangan pariwisata. Penelitian ini bertujuan untuk mengidentifikasi persepsi wisatawan terhadap transportasi wisata (KM Sabuk Nusantara 66) sebagai daya tarik bagi wisatawan yang mengunjungi Kepulauan Seribu dari pelabuhan sunda kelapa. Penelitian ini mengadopsi pendekatan kualitatif dengan teknik pengumpulan data triangulasi. Lokasi penelitian dilakukan di Pelabuhan Sunda Kelapa, dengan melibatkan Nahkoda kapal (PT. Pelni) dan staff KSOP Pelabuhan Sunda Kelapa dengan jumlah sampel ditentukan menggunakan teknik purposive sampling. Sedangkan wisatwan ditentukan dengan tehnik judgmental sampling. Pengumpulan data ini dilakukan selama tiga bulan, dari bulan Mei sampai Juli 2018. Penelitian ini menemukan bahwa kelayakan Kapal KM Sabuk Nusantara 66 ini sesuai dengan persepsi wisatawan berdasarkan 10 indikator faktor transportasi untuk penunjang pariwisata. Penelitian ini dapat digunakan sebagai saran pengembangan operator kapal serta pengelola destinasi untuk terus meningkatkan kualitas pelayanan. Penelitian ini memiliki keterbatasan pada sampel perusahaan transportasi yang terlibat. Penelitian selanjutnya diharapkan dapat menjangkau sampel yang lebih luas atau bahkan merambah pada jenis transportasi lainnya, seperti kereta wisata, bus wisata, atau bahkan transportasi udara.
\end{abstract}

Kata kunci : Transporasi, Daya Tarik Wisata, Persepsi Wisatawan, Kepulauan Seribu 


\section{PENDAHULUAN}

Secara teori, sebagai sebuah sistem yang terintegrasi, daya tarik dan aksesibilitas memainkan peran yang cukup esensial dalam pengembangan pariwisata secara umum. Tentu tanpa mengurangi peran faktor-faktor lain seperti amenities; ancillary services; activities; available packages; community empowerment dan investments/Incentive (Wiweka \& Arcana, 2019). Asumsi ini seolah dipertegas oleh sejarah perkembangan pariwisata di berbagai belahan dunia yang sebagian besar diinisiasi oleh pergerakan (movement) manusia untuk mencari pengalaman atau daya tarik tertentu.

Beberapa catatan sejarah yang dapat memperkuat gagasan tersebut diantara-Nya bagaimana terminologi pariwisata yang saat ini berkembang mungkin dipengaruhi perkembangan istilah "tourist" di Eropa yang dipercaya telah dipicu pada tahun 1672, melalui buku berjudul "The True Guide For Foreigners Travelling in France to Appreciate Its Beauties, Learn the Language and Take Exercise" yang ditulis oleh seorang bangsawan dari St. Maurice yang menggambarkan tentang suasana kota Paris. Lalu kemudian di abad ke-18, istilah "tourist" atau "wisatawan" mulai dikenal bersamaan dengan populernya istilah "to make the grand tour" di Inggris untuk merujuk perjalanan ke benua Eropa yang diwajibkan sebagai syarat kelengkapan Pendidikan bagi para golongan muda dan terpelajar. Istilah ini (tourist) kemudian oleh novelis prancis bernama Stendhal melaui Stendhal's Memoires d'un Touriste diperuntukan bagi seseorang yang melakukan perjalanan dengan tujuan kesenangan (kenikmatan)(Arcana \& Wiweka, 2015). (Duhamel, 2018) ${ }^{1}$ secara

\footnotetext{
1"touriste apparait en 1800 en anglais, en 1803 en français et en 1975 en allemande. Le mot (tourisme) apparait après: en 1811 en anglais et en 1841 en francais... Et quand les mots apparaissent, cela signifie que la pratique existe et qu'elle est suffisamment développée et originale pour nécessiter un néologisme. Pourtant, s'il est inventé, le tourisme est un voyage
}

qui s'inscrit en filiation avec le Grand Tour et les mobilités de (sante) vers les villes d'eaux... (Duhamel, 2018)."

spesifik mencatat istilah "tourist" awalnya muncul di Inggris pada tahun 1800, kemudian di Prancis (1803), dan German pada 1975. Istilah tersebut diikuti munculnya istilah "tourism", yang dikenal di Inggris pada tahun 1811 dan di Prancis pada 1841. Era ini juga dikenal sebagai awal dari perkembangan "industri pariwisata modern" (Duhamel, 2018; Spillane, 1991; Tribe, 2009).

Sedangkan di Indonesia, istilah pariwisata pertama kali diperkenalkan oleh dua budayawan pada sekitar tahun 1960, yaitu Moh. Yamin dan Prijono. Kedua budayawan ini memberikan masukan kepada pemerintah saat itu untuk mengganti istilah tour agar sesuai dengan bahasa khas Nusantara. Istilah Pariwisata sendiri berasal dari bahasa Sangsekerta yang terdiri dari Pari (Penuh, Lengkap, Keliling), Wis (man) (Rumah, properti, Kampung, Komunitas, dan Ata (Pergi, Terus Menerus, Mengembara). Yang bila diartikan secara keseluruhan, pariwisata adalah Pergi Secara Lengkap, Meninggalkan Rumah (Kampung) untuk berkeliling secara terus menerus (Nyoman, 2002). Definisi ini juga yang diyakini mempengaruhi perumusan definisi "wisatawan" yang tertuang pada Instruksi Presiden No. 9/1969, dimana "Wisatawan adalah setiap orang yang bepergian dari tempat tinggalnya untuk berkunjung ke tempat lain dengan menikmati perjalanan dari kunjungan itu" (Setiawan et al., 2018; Spillane, 1991; Wiweka, Wachyuni, Simawang, et al., 2019).

Seperti halnya fenomena "grand tour" di Eropa yang dipercaya telah mempengaruhi secara signifikan pola perpindahan wisatawan modern. Di Indonesia, dibukanya Terusan Suez pada 1870 memberikan perubahan terhadap jalur masuk ke Hindia. Demikian halnya dengan sarana transportasi yang digunakan di Hindia-Belanda, seperti kereta api yang digunakan setelah 1870-an, telah 
memberikan dampak pada peta perjalanan manusia. Meskipun catatan sejarah yang mendominasi setelah 1870 merupakan perspektif Eropa dan Amerika, namun Pada periode sebelum 1870, bahkan beberapa abad sebelumnya, terdapat catatan perjalanan (Ong Tae Hae, The Chinaman Abroad on a Desultory Account of the Malayan Archipelago, Particularly of Java) orang Asia (China) ke Hindia. Salah satunya adalah Wang Ta-Hai yang tercatat pernah melakukan perjalanan ke Nusantara (Indonesia) pada 1783 (Spillane, 1991; Sunjayadi, 2017). Perjalanan seperti ini, dipercaya juga telah dilakukan oleh nenek moyang bangsa Indonesia sejak zaman kerajaan HinduBudha pada abad ke-4 hingga ke-16.

Meskipun catatan dan bukti sejarah sangat terbatas, namun diyakini pada masa awal abad ke-19, Negara-negara "penguasa" telah memberikan pengaruh kuat pada kegiatan pariwisata di wilayah Asia tenggara. Beberapa negara tersebut adalah Inggris di Malaya dan Singapura, Prancis di Indo-China, seta Belanda di Hindia-Belanda (Indonesia). Saat itu, aktivitas pariwisata yang berkembang di Hindia-Belanda adalah perjalanan dengan motivasi utama bersenang-senang. Akan tetapi, aktor atau pelakunya (yang saat ini dikenal dengan istilah wisatawan atau pengunjung) masih terbatas pada kalangan bangsawan. Fenomena ini mengingatkan kita pada Era Grand Tour (McIntosh et al., 1995; Simanjuntak et al., 2017; Spillane, 1991) yang berkembang di Eropa (tujuan utama ke Prancis dan Italy).

Saat itu, selain dari akses informasi yang telah beredar di Eropa melalui buku, artikel dan media lain. Hindia-Belanda juga mulai dikunjungi saat akses fisik (laut) mulai memungkinkan. (Sunjayadi, 2017) mencatat bahwa, dibukanya Terusan Suez (1869) mendorong peningkatan permintaan perjalanan antara Belanda dan Hindia-Belanda. Pada awalnya (1879) kanal Holland (Amsterdam) dan (18771880) beberapa pelabuhan di HindiaBelanda (Padang, Penang, dan Aceh) digunakan sebagai penghubung. Adapun perusahaan asing yang melayani jalur ini (Batavia, Semarang) antara lain perusahaan pelayaran Perancis (Compagnie des Messageries Maritimes), Inggris (Peninsular and Oriental steam Navigation Company-P\&O, Queensland Royal Mail Line, dan British India Steam Navigation Company), dan Jerman (Norddeutsche Lloyd).

Sedangkan untuk transportasi laut di dalam negeri, awalnya (1850) pemerintah Hindia-Belanda hanya memiliki dua buah kapal uap, dengan rute sepanjang Pantai Utara Jawa dan jalur Surabaya-Makassar. Kemudian pada tahun 1853, bekerja sama dengan W. Cores de Vries, rute pelayaran diperluas menjadi Batavia-Padang, Batavia-SemarangSurabaya-Makassar, Surabaya-Makassar, Makassar-Ambon-Ternate-Manado

(Sunjayadi, 2017). Pada periode ini, pulau yang lebih banyak menarik perhatian adalah Jawa, hal ini dikarenakan para pengunjung belum merasa aman pada daerah-daerah Hindia lain yang belum dikuasai olah Belanda. Alasan ini juga yang membuat Batavia mendominasi sebagai akses masuk utama kapal-kapal asing.

Catatan sejarah ini menunjukkan bagaimana transportasi telah memainkan peran yang cukup penting dalam perkembangan pariwisata di dunia, bahkan di Indonesia, hingga saat ini. Palhares bahkan mengungkapkan bahwa, "transportasi adalah faktor yang paling penting yang berkontribusi terhadap keberhasilan industri pariwisata" (Van Truong \& Shimizu, 2017). Dalam perspektif modern, aksesibilitas tidak hanya terbatas pada sarana fisik. Meminjam gagasan Le-Klähn and Hall yang berpendapat bahwa "Accessibility is not only defined as providing ability to tourists to reach destinations, but also by the use of transportation services at destinations once they arrive. These accessibility factors influence tourists' impressions during their trip, and serve as 
determining factors of the destinations' overall attractiveness" (Van Truong \& Shimizu, 2017).

UNWTO (2016) mencatat transportasi yang paling banyak digunakan oleh wisatawan adalah transportasi udara sekitar 55\%, sementara transportasi darat melalui mobil dan bus sebanyak 39\%, transportasi air sebanyak $4 \%$, sedangkan transportasi darat dengan kereta api sebanyak 2\% (Mohamed, 2019). Jika dibandingkan diantara ketiga jenis mode transportasi, transportasi air masih belum dimanfaatkan secara optimal. Namun, di beberapa kota pada negara-negara maju, jenis transportasi ini bahkan telah dimanfaatkan sebagai daya tarik utama. Artinya banyak wisatawan yang datang berkunjung justru karena daya tarik transportasinya. Sebut saja keberadaan water taxi atau water bus di kota Venesia (Italia) (Imboden, 2020) dan kapal pesiar yang bernama Bateaux-Mouches (fly-boat) yang merupakan operator kapal pesiar dan perahu tur paling terkenal dan terbesar di Paris (Prancis) tepatnya di sungai Seine (www.bateaux-mouches.fr/en, 2020). Tidak hanya transportasi air, cable car (kereta gantung), funiculars (kereta furnikuler), dan cogwheel (kereta cogwheel) telah menjadi daya tarik bagi wisatawan yang ingin menuju pegunungan alpen di Swiss (Myswissalps, 2020). Di Inggris, tepatnya di kota London, transportasi kereta telah menjadi tren sejak tahun 1963 sampai saat ini. Kereta bawah tanah atau yang biasa dikenal dengan London Underground atau biasa disebut juga dengan tube merupakan sistem angkutan cepat tertua di dunia yang hingga kini masih mampu menjadi daya tarik bagi wisatawan (Visitlondon, 2020). Bahkan, saat ini pengembangan transportasi wisata yang dapat dikatakan paling ambisius adalah bagaimana Dubai yang merupakan kota pertama yang memperkenalkan Drone Taxi atau taksi terbang tanpa awak yang di atur oleh ground control systems. Transportasi ini diklaim sebagai solusi transportasi paling aman, cerdas, dan ramah lingkungan (Wakefield, 2020).

Beberapa contoh tersebut menunjukkan bagaimana pariwisata telah mendorong evolusi transportasi dalam meningkatkan kemampuan perjalanan jarak jauh, kecepatan perjalanan, waktu perjalanan, dan tingkat kenyamanan (Van Truong \& Shimizu, 2017). Di Indonesia, pemerintah melalui kementerian perhubungan sedang mengembangkan aksesibilitas di berbagai wilayah Indonesia. Saat ini pembangunan sarana fisik seperti jalan tol, pelabuhan, bandar udara, dan jalur kereta, hingga sarana transportasi seperti MRT, LRT, hingga kereta cepat, sedang terus dikembangkan guna menyusul ketertinggalan dari berbagai negara maju lainnya. Tidak hanya dari sisi kuantitas dan kualitas, pembangunan ini juga kini mempertimbangkan konektivitas yang lebih terintegrasi. Selain itu, pembangunan juga tidak hanya dikonsentrasikan di Ibu Kota, namun juga hingga menjangkau daerah-daerah terluar Indonesia.

Jakarta sebagai Ibu Kota Negara, merupakan salah satu destinasi prioritas melalui kepulauan seribu. Badan Pusat Statistik (BPS, 2020) mencatat bahwa berdasarkan SK Gubernur, ada sebanyak 110 pulau di wilayah Kepulauan Seribu. Sebanyak 45 pulau difungsikan sebagai pulau wisata umum, 4 pulau bersejarah, 2 pulau cagar alam, dan ada 5 pulau yang masuk dalam kategori pulau resort. Jumlah tersebut belum termasuk pulau-pulau kosong yang sering juga dimanfaatkan wisatawan untuk camping. Kepulauan seribu merupakan wilayah yang sebagian besar wilayahnya adalah perairan, total luas wilayah daratan Kabupaten Administrasi Kepulauan Seribu adalah 897.71 Ha dan luas perairan Kepulauan Seribu mencapai 6.997,50 Km2. Ditinjau dari kondisi geografisnya maka transportasi air merupakan sarana transportasi yang dominan dimanfaatkan untuk membawa manusia atau barang (Seribu, 2020). 
Untuk menjangkau Kepulauan Seribu, saat ini wisatawan dapat menggunakan kapal yang tersedia di enam pelabuhan yaitu, Pelabuhan Kali Adem, Pelabuhan Muara Angke Pelabuhan Sunda Kelapa, Pelabuhan Marina, Pelabuhan Rawasaban, dan Pelabuhan Tanjung Pasir. Data statistik menunjukkan bahwa pulau yang paling banyak dikunjungi oleh wisatawan dari periode bulan Januari sampai Desember, adalah Pulau Untung Jawa, Pulau Pramuka, dan Pulau Kelapa (jakarta-tourism.go.id, 2020).

Transportasi air yang saat ini menjadi penunjang untuk wisatawan melakukan penyebrangan ke Kepulauan Seribu adalah, speed boat (Pelabuhan Marina), kapal KM Sabuk Nusantara 66 (Pelabuhan Sunda Kelapa), kapal KM kerapu (Pelabuhan Kali Adem), kapal kayu atau kapal tradisional (Pelabuhan Muara Angke, Rawa Saban, Tanjung Pasir). KM Sabuk Nusantara 66 yang terletak di Pelabuhan Sunda Kelapa, yang diresmikan oleh PT. Pelni pada tanggal 24 Mei 2017 dan dioperasikan pada tanggal 25 Mei 2017. Penempatan kapal ini di Kepulauan Seribu DKI Jakarta merupakan wujud komitmen Kementerian Perhubungan untuk terus meningkatkan kualitas pelayanan transportasi kepada masyarakat. Khususnya di Kepulauan Seribu yang selama ini masih terbatas aksesibilitasnya.

KM Sabuk Nusantara 66 melayani 3 rute Pulau di Kepulauan Seribu, yakni Pulau Untung Jawa, Pulau Pramuka, dan Pulau Kelapa. Jadwal keberangkatan KM Sabuk Nusantara 66 ialah hari Senin, Rabu, dan Sabtu, dengan dikenakan tarif sebesar Rp. 15,000 yang sudah termasuk dengan biaya asuransi perjalanan. KM Sabuk Nusantara 66 merupakan kapal perintis buatan PT Karimun Marine Shipyard, dan memiliki spesifikasi panjang 42 meter, lebar 9 meter, tinggi 4 meter, kecepatan 12 Knot. Fasilitas yang terdapat di KM Sabuk Nusantara 66 cukup baik yang telah disediakan oleh pemerintah seperti, di deck utama terdapat 42 tempat duduk dengan pendingin ruangan, mini cafeteria yang berisi makanan dan minuman ringan, dua toilet masing-masing untuk laki-laki dan perempuan, dan mushola. Lalu di deck bawah terdapat tempat tidur tingkat dengan kapasitas 72 orang, sehingga kapasitas penumpang untuk kapal ini menampung 114 orang.

Faktanya, statistik menunjukkan bahwa wisatawan yang menggunakan KM Sabuk Nusantara 66 melampaui kapasitas di beberapa periode bulan tertentu (dephub.go.id, 2020). Pada bulan Mei jumlah wisatawan terbanyak ada pada hari Sabtu. Selanjutnya pada bulan Juni jumlah wisatawan terbanyak ada pada hari Senin dan Rabu di minggu ke-4. Lalu, pada bulan Juli jumlah wisatawan terbanyak ada pada hari Sabtu di minggu ke- 1, 2, dan 3. Pada bulan Agustus, jumlah wisatawan terbanyak ada pada hari Senin dan Rabu di minggu ke-3 dan 4. Pada bulan September tidak ada aktivitas pelayaran ke Kepulauan Seribu karena kapal KM Sabuk Nusantara 66 melakukan docking atau perbaikan kapal dan pengecekan keseluruhan mesin kapal. Pada bulan Oktober jumlah wisatawan terbanyak ada pada hari Sabtu di-empat minggu berturut-turut. Selanjutnya pada bulan November jumlah wisatawan terbanyak ada pada hari Sabtu di minggu ke-1. Dan pada bulan Desember jumlah wisatawan terbanyak ada pada hari Sabtu di minggu ke-3 dan ke-4. Dapat dikatakan bahwa kapal KM Sabuk Nusantara 66 digunakan oleh wisatawan untuk berwisata ke Kepulauan Seribu yang didominasi pada saat akhir pekan. Sementara untuk hari Senin dan Rabu digunakan oleh masyarakat Kepulauan Seribu untuk mobilitas kegiatannya.

Namun apabila dibandingkan dengan wisatawan yang menggunakan kapal dari seluruh pelabuhan yang ada di Jakarta, statistik menunjukkan bahwa dapat dikatakan masih sedikit wisatawan yang menggunakan kapal ini untuk ke Kepulauan Seribu. Sedangkan bila melihat dari segi kapasitas kapal yang memiliki daya tampung sebesar 114 (dephub.go.id, 
2020) maka berdasarkan kapasitas tersebut kapal ini dapat dikatakan telah dimanfaatkan secara maksimal oleh penumpang (baik wisatawan atau masyarakat umum).

Data tersebut menunjukkan bahwa transportasi air khususnya kapal wisata yang berjenis tradisional maupun kapal motor (modern) sangat diminati oleh wisatawan yang hendak melakukan pelayaran ke Kepulauan Seribu. Namun transportasi ini sendiri tidak hanya dimanfaatkan oleh wisatawan, namun juga masyarakat lokal yang hendak beraktivitas. Interaksi keduanya tentu dapat memberikan pengalaman yang berbeda bagi wisatawan. Selain itu, isu yang cukup esensial dari jenis transportasi ini adalah faktor keamanan dan keselamatan perjalanan. Kedua faktor ini merupakan standar terpenting yang wajib dimiliki oleh perusahaan penyedia jasa transportasi. Adapun fenomena yang berkembang di Indonesia, beberapa perusahaan kerap mengabaikan faktor tersebut. Asumsi ini diperkuat dengan adanya beberapa kasus kecelakaan yang terjadi belakangan ini. Salah satunya ialah kapal motor Sinar Bangun yang saat itu dalam pelayaran rute Pelabuhan Simanindo Kabupaten Samosir menuju Pelabuhan Tiga Ras tenggelam menjelang satu mil tiba di tujuan (Kompas, 2018). Selain itu, tenggelamnya kapal motor Arista di perairan selat Makassar, dalam perjalanan dari Pelabuhan Paotere menuju ke Pulau Baranglompo ketika dihantam angin dan ombak besar di perairan antara Pulau Kayangan dan Tanggul Reklamasi (Voaindonesia.com, 2018).

Beberapa isu tersebut dapat mempengaruhi minat wisatawan dalam memanfaatkan transportasi air sebagai media transportasi utama, atau bahkan memosisikan transportasi sebagai daya tarik wisata utama. Oleh karenanya penelitian ini bertujuan untuk mengidentifikasi persepsi wisatawan terhadap transportasi wisata sebagai daya tarik bagi wisatawan yang mengunjungi kepulauan seribu dari pelabuhan sunda kelapa. Sedangkan secara khusus penelitian ini berupaya mengidentifikasi karakteristik kapal wisata di Pelabuhan Sunda Kelapa (KM Sabuk Nusantara 66), karakteristik wisatawan atau penumpang, dan persepsi wisatawan terhadap kapal KM Sabuk Nusantara 66. Adapun studi kasus yang menjadi fokus penelitian adalah penumpang kapal KM Sabuk Nusantara 66. Penelitian ini diharapkan dapat memberikan informasi terkait dengan preferensi wisatawan terhadap transportasi wisata, khususnya transportasi air. Selain itu temuan penelitian ini juga dapat dimanfaatkan oleh para pelaku bisnis transportasi wisata secara umum, dan transportasi air khususnya, dalam mengkaji harapan wisatawan terhadap transportasi wisata. Penelitian ini juga memiliki keterbatasan pada sampel perusahaan transportasi yang terlibat. Penelitian selanjutnya diharapkan dapat menjangkau sampel yang lebih luas atau bahkan merambah pada jenis transportasi lainnya, seperti kereta wisata, bus wisata, atau bahkan transportasi udara.

\section{TINJAUAN LITERATUR}

Penelitian ini menggunakan beberapa teori dan kosep utama dalam membedah fenomena persepsi wisatawan pada transportasi wisata sebagai daya tarik. Beberapa teori dan konsep yang digunakan terkait dengan aksesibilitas, transportasi, persepsi wisatawan, hingga pelabuhan. Aksesibilitas, khususnya aspek transportasi, merupakan satu kesatuan sistem pariwisata yang terintegrasi dengan komponen lainnya. (Cooper, 2008)menjabarkan atribut "amalgam" destinasi wisata ke dalam empat komponen, yang dikenal dengan empat As. Yang diantaranya adalah: (i) Attractions (atraksi); (ii) Accessibilities (aksesibilitas); (iii) Amenities (amenitas atau fasilitas penunjang pariwisata); (iv) Ancillary service (organisasi penunjang kegiatan pariwisata). Sedangkan (Buhalis, 
2000)menjabarkan destination sebagai suatu kesatuan (amalgam) tourism products and services yang menawarkan suatu pengalaman yang terintegrasi bagi konsumen (tourist). Sebagian besar destinasi wisata terdiri dari beberapa komponen utama yang bisa disebut six As: Attraction (natural, man-made, artificial, purpose built, heritage, special events), Accessibility (entire transportation system comprising of routes, terminals and vehicles), Amentities (accommodation and catering facilities, retailing, other tourist services), Available packages (prearranged packages by intermediaries and principals), Activities (all activities available at the destination and what consumers will do during their visit), Ancillary services (services used by tourist such as banks, telecommunication, post, newsagents, hospitals, etc.). Dengan kata lain, aksesibilitas atau transportasi merupakan bagian dari destinasi wisata yang ditawarkan kepada wisatawan dalam bentuk produk atau jasa (Buhalis, 2000; Cooper, 2008). Sedangkan (Wiweka \& Arcana, 2019) berpendapat bahwa tourism destination region dapat didefinisikan sebagai lokasi yang dapat menarik wisatawan untuk tinggal sementara, khususnya dengan adanya elemen-elemen yang melekat pada bisnis pariwisata seperti yang dikenal dengan '6ACI' yang membentuk the tourist supply, diantaranya attractions; accessibilities; amenities; ancillary services; activities; available packages; community empowerment dan investments/Incentive (Wiweka \& Arcana, 2019).

\section{Accessibility}

Aksesibilitas adalah salah satu elemen yang menghubungkan antara wisatawan dan atraksi wisata serta fasilitas pariwisata lainnya. Elemen ini memberikan kemudahan bagi wisatawan untuk menjangkau berbagai daerah yang menawarkan produk wisata. Selain mudah dikunjungi secara fisik, baik melalui darat, laut, dan udara. Sebaiknya, destinasi wisata juga menawarkan aspek kemudahan non-fisik bagi wisatawan, seperti kemudahan menjangkau secara informasi yang detail tentang segala kebutuhan dan keinginan mereka. Akses informasi tersebut dimanfaatkan oleh sebagian besar wisatawan sebagai pusat informasi wisata. Selain itu kemudahan regulasi, dimana regulasi pemerintah (government regulation). Seperti, pada sebagian besar kawasan Eropa yang memberikan kemudahan, dalam hal visa (Wiweka \& Arcana, 2019). Selain pengertian secara luas, transportasi juga dapat dikategorikan sebagai aksesibilitas karena mampu memberikan kemudahan bagi wisatawan untuk menjangkau destinasi wisata (Kusmayadi et al., 2019).

\section{Transportasi}

Transportasi berasal dari kata Latin "transportare", trans berarti seberang atau sebelah lain dan portare berarti mengangkut atau membawa. Jadi, transportasi berarti mengangkut atau membawa (sesuatu) ke sebelah lain atau suatu tempat ke tempat lainnya. Transportasi dapat didefinisikan sebagai suatu usaha dan kegiatan mengangkut atau membawa barang dan atau penumpang dari suatu tempat ke tempat lainnya. Transportasi sebagai sebuah sistem terdiri dari lima unsur utama, yaitu Orang atau Barang yang membutuhkan; Kendaraan sebagai alat angkut; Jalan sebagai prasarana angkutan; Terminal; dan Organisasi sebagai pengelola angkutan.

Pengangkutan atau pemindahan penumpang atau barang dengan transportasi dilakukan untuk dapat mencapai tempat tujuan dan menciptakan atau meningkatkan kegunaan dari barang yang diangkut. Utilitas yang dapat diciptakan oleh transportasi atau pengangkutan dapat dikategorikan menjadi dua, yaitu utilitas tempat (Place Utility) dan utilitas waktu (Time Utility) (Siregar, 2012). 
Keberadaan sarana transportasi air sangat penting bagi perkembangan pariwisata nasional. Dimana moda transportasi ini mampu mencapai pulaupulau kecil, terutama yang tidak dapat dicapai oleh alat transportasi lain, menggunakan sumber daya alam (perairan), harga yang relative terjangkau namun nilai investasi yang tergolong relative tinggi (pembelian kapal, pemeliharaan, perawatan), dan mampu mengangkut banyak penumpang dan barang (Ismayanti, 2010).

Untuk mengkaji persepsi wisatwan yang menggunakan KM Sabuk Nusantara 66 di Kepulauan Seribu, peneliti menggunakan 10 dari 12 faktor transportasi yang mempengaruhi keterjangkauan tujuan wisata berdasarkan Litman (2008), diantaranya Moda transportasi (kualitas pilihan transportasi; kenyamanan, dan keamanan); Konektivitas jaringan transportasi (kelancaran perjalanan antar tujuan); Biaya perjalanan atau keterjangkauan; Mobilitas (kecepatan dan jarak perjalanan, kapasitas, atau waktu tempuh); Integrasi tautan dan moda dalam sistem transportasi; Permintaan transportasi; Informasi pengguna (ketersediaan informasi yang dapat diandalkan tentang pilihan mobilitas dan aksesibilitas); Pengganti mobilitas (pengganti layanan telekomunikasi dan pengiriman untuk perjalanan fisik); Manajemen transportasi; dan Prioritas kegiatan perjalanan (Van Truong \& Shimizu, 2017). Sedangkan dua faktor lainnya (faktor lingkungan dan isolasi) tidak digunakan dengan pertimbangan pengetahuan dan wawasan penumpang.

\section{Pelabuhan}

Seperti yang telah dijabarkan pada bagian pendahuluan, bahwa Pelabuhan telah memainkan peranan yang sangat penting bagi banyak negara dan destinasi, sebagai gerbang yang memungkinkan pihak lain untuk mengunjungi suatu tempat. Secara historis, dibukanya terusan suez telah memberikan dampak yang signifikan bagi dikenalnya Indonesia oleh negara lain. Pelabuhan adalah tempat yang terdiri atas daratan dan atau perairan dengan batas batas tertentu sebagai tempat kegiatan pemerintahan dan kegiatan pengusahaan yang dipergunakan sebagai tempat kapal bersandar, naik turun penumpang, dan atau bongkar muat barang, berupa terminal dan tempat berlabuh kapal yang dilengkapi dengan fasilitas keselamatan dan keamanan pelayaran dan kegiatan penunjang pelabuhan serta sebagai tempat perpindahan intra dan antarmoda transportasi.

Dalam kedudukan pelabuhan sebagai sub system terhadap pelayaran, dan mengingat pelayaran sendiri adalah pembawa bendera mengikuti pola perdagangan (ship follows the trade), maka pelabuhan menjadi salah satu unsur penentu terhadap aktivitas perdagangan. Pelabuhan yang dikelola secara efisien akan mendorong kemajuan perdagangan. Sehingga dapat dikatakan pelabuhan berperan sebagai focal point bagi perekonomian maupun perdagangan, dan menjadi kumpulan badan usaha seperti pelayaran dan keagenan,pergudangan, freight forwarding, dan angkutan darat. Peranan pelabuhan meliputi melayani kebutuhan perdagangan internasional dari daerah dimana pelabuhan tersebut berada, membantu berputarnya roda perdagangan dan pengembangan industry regional, menampung pangsa pasar yang makin meningkat dari lalu lintas internasional, baik transhipment maupun barang, serta menyediakan fasilitas transit untuk daerah belakang atau daerah/negara tetangga (Siregar, 2012).

\section{Wisatawan}

Setelah membahas transportasi sebagai bagian dari destinasi wisata, maka pertanyaan selanjutnya adalah siapa subjek (aktor) yang melakukan aktivitas tersebut?. Ada berbagai sumber dan literatur yang telah menjabarkan siapa subjek yang melakukan aktivitas tersebut. Diantaranya, 
according to The American Heritage Dictionary, the word tourist is derived from the word 'tour-ist' (noun) which means something related to 'traveling for pleasure'. The definition is resulted through the combination of the word 'travel' and 'pleasure' into one word, 'tourist'. However, based on Stendhal 's Memoires d'un Touriste, it appears that the word 'tourist' had been introduced and used by French peoples since 1838 in referring to people who visit England or in referring to the practices of the English people. But the word was then more commonly associated to travelling for pleasure after Stendhal "es book, which coincided with the beginnings of the 'modern tourist industry' (Tribe, 2009). Sedangkan (Leiper, 1979) mencatat perkembangan definisi pariwisata dan wisatawan sejak 1930's, dimana wisatawan dalam lingkup praktis menurut League of Nation Statistical Committee (1937) adalah seorang yang mengunjungi suatu negara diluar tempat tinggalnya dan menetap setidaknya selama 24 jam dengan berbagai tujuan untuk menikmati waktu luang dan melakukan bisnis. Namun secara sederhana UU No. 10 th 2009 RI menterjemahkan wisatawan sebagai orang yang melakukan wisata.

Wisatawan selanjutnya juga telah diklasifikasikan secara lebih spesifik, dimana (Cohen, 1972) membagi tipologi wisatawan menjadi empat jenis, diantaranya adalah the organized mass tourist, dimana jenis wisatawan ini melakukan perjalanan dengan membeli paket wisata dan sudah sangat terencana (well-prepared); sedangkan the individual mass tourist, adalah jenis wisatawan yang masih "mirip" dengan yang sebelumnya, namun jenis wisatawan ini masih memiliki kontrol untuk mengatur perjalanan mereka sendiri pada beberapa waktu diluar group, meskipun sebagian besar aktivitas masih direncanakan oleh agen perjalanan; sedangkan the explorer, merupakan jenis wisatawan yang mengatur perjalanannya sendiri dengan mengunjungi tempat yang terpencil. Namun wisatawan pada jenis ini cenderung masih memperhatikan kenyamanan akomodasi dan transportasi; sedangkan yang terakhir adalah the drifter, dimana jenis wisatawan ini cenderung mencari hal baru diluar rutinitas seharihari dan mencoba untuk hidup seperti apa yang dilakukan masyarakat lokal di destinasi (adanya kontak langsung). Mereka juga terkesan tidak memiliki rencana dan tujuan perjalanan yang pasti.

\section{Persepsi wisatawan}

Persepsi adalah suatu proses bagaimana wisatwan menyeleksi, mengatur, dan menginterpretasikan segala informasi untuk menciptakan atau merepresentasikan gambaran keseluruhan fenomena. Persepsi juga dapat dikatakan sebagai suatu proses mengelompokan atau kategorisasi dan interpretasi yang bersifat selektif. Adapun faktor yang mempengaruhi persepsi wisawatan adalah katakteristik sesuatu yang dipersepsi dan faktor situasional (Kotler et al., 2007). Penelitian ini fokus pada persepsi wisatwan yang berkunjung ke kepulauan seribu melalui pelabuhan sunda kelapa, terhadap Kapal KM Sabuk Nusantara 66.

\section{METODE, DATA, DAN ANALISIS}

Penelitian ini mengadopsi
pendekatan kualitatif dengan teknik
pengumpulan data triangulasi (Sugiono,
2010). Pendekatan ini dianggap sesuai
untuk membedah fenomena persepsi
wisatwan di Kepulauan Seribu terhadap
transportasi wisata, khususnya KM Sabuk
Nusantara 66. Penelitian ini dilakukan di
Pelabuhan Sunda Kelapa, dengan
melibatkan Nahkoda kapal (PT. Pelni) dan
staff KSOP Pelabuhan Sunda Kelapa
dengan umlah sampel ditentukan
menggunakan teknik purposive sampling.
Sedangkan wisatwan ditentukan dengan
tehnik judgmental sampling dengan
formula Slovin sebagai berikut.




$$
n=\frac{\mathrm{N}}{1+N(e)^{2}}
$$

Dimana:

[n] merupakan jumlah sampel

[N] merupakan total populasi

[e] merupakan persentase kelonggaran ketidaktelitian karena kesalahan (5-10\%)

[1] merupakan konstanta.

Berdasarkan data jumlah populasi (3.011) yang telah diketahui dan jumlah persentase kelonggaran yang telah ditentukan adalah $10 \%$, maka penelitian ini melibatkan 100 responden (wisatwan) sebagai sampel penelitian ini.

$$
\begin{aligned}
& n=\frac{3011}{1+3011(10)^{2}}=\frac{3011}{1+30,11} \\
& =96,78 \\
& n=100 \text { (dibulatkan) } \\
& \text { Kuesioner didistribusikan secara } \\
& \begin{array}{l}
\text { langsung kepada wisatawan atau } \\
\text { penumpang pada saat Kapal KM Sabuk }
\end{array}
\end{aligned}
$$

Nusantara 66 berlayar ke Kepulauan Seribu. Pengumpulan data ini dilakukan selama tiga bulan, dari bulan Mei sampai Juli 2018. Data yang diperoleh melalui berbagai sumber kemudian diolah, dianalisa secara deskriptif dengan dasar teori dan konsep yang telah dijabarkan pada bagian tinjauan literatur.

\section{HASIL DAN PEMBAHASAN}

\section{Karakteristik Kapal Wisata KM Sabuk Nusantara 66}

Peneliti melakukan observasi dan wawancara dengan staf seksi lalu lintas laut sebagai pengawas kapal dan nahkoda dari PT Pelni yang merupakan operator KM Sabuk Nusantara. Observasi dan

\begin{tabular}{|c|c|c|}
\hline No. & $\begin{array}{c}\text { Elemen } \\
\text { transportasi }\end{array}$ & Hasil observasi dan wawancara \\
\hline 1. & Moda & $\begin{array}{l}\text { Kapal KM Sabuk Nusantara } 66 \text { diperuntukan pelayaran antarpulau, yaitu di } \\
\text { Kepuluan Seribu dengan } 3 \text { rute pulau utama, Pulau Untung Jawa, Pulau } \\
\text { Pramuka, Pulau Kelapa. Mesin yang digunakan oleh kapal KM Sabuk } \\
\text { Nusantara } 66 \text { ialah mesin diesel dengan } 2 \text { penggerak, } 2 \text { baling baling, dan } 1 \\
\text { push power mesin. Kapal KM Sabuk Nusantara } 66 \text { memiliki spesifikasi } \\
\text { panjang seluruh kapal } 44,30 \mathrm{~m}^{2} \text { dengan lebar } 39,95 \mathrm{~m}^{2} \text { dan volume } \\
\text { kedalaman kapal } 3.600 \mathrm{~m}^{3} \text {. Kapal memiliki } 21 \mathrm{ABK} \text { (anak buah kapal) } \\
\text { dengan } 6 \text { perwira. Fasilitas penunjang lengkap dari pelampung, APAR, } \\
\text { hingga asuransi jiwa. }\end{array}$ \\
\hline 2. & Jalan & $\begin{array}{l}\text { kemampuan jarak keseluruhan yang dapat ditempuh oleh kapal KM Sabuk } \\
\text { Nusantara } 66 \text { adalah } 40 \text { Mil. Kapal ini memiliki } 3 \text { jenis kecepatan } \\
\text { maksimum yang disesuaikan dengan kebutuhan dan cuaca yakni, kecepatan } \\
\text { ekonomis sebesar } 9 \text { knot/perjam, kecepatan rendah (pada saat olah gerak } \\
\text { atau kapal bersandar) } 4 \text { knot/ perjam, dan kecepatan maksimal } 12 \\
\text { knot/perjam. }\end{array}$ \\
\hline 3. & Terminal & $\begin{array}{l}\text { Terminal yang dimaksud adalah pelabuhan Sunda Kelapa. pelabuhan sunda } \\
\text { kelapa memiliki beberapa fasilitas seperti, toilet portable, penunjuk arah } \\
\text { lokasi, tempat ibadah, dan warung makan, serta disediakan angkutan } \\
\text { Transjakarta gratis dari stasiun kota ke pelabuhan. }\end{array}$ \\
\hline 4. & Teknologi & $\begin{array}{l}\text { Informasi terkait Kapal KM Sabuk Nusantara } 66 \text { dapat diakses di website } \\
\text { PT Pelni, namun metode pemesanan masih harus dilakukan secara } \\
\text { konvensional atau secara langsung. Terkait biaya perjalanan tergolong } \\
\text { terjangkau yaitu Rp } 15.000 \text {,- per orang, bahkan untuk yang membawa } \\
\text { kendaraan tidak dikenakan tarif khusus. }\end{array}$ \\
\hline
\end{tabular}
wawancara dilakukan berdasarkan empat elemen transportasi, yaitu moda, jalan, terminal, dan teknologi. Adapun hasil observasi dan wawancara dapat dilihat pada Tabel 1.

Tabel 1. Hasil Wawancara

Sumber: analisis peneliti, 2020 
Secara umum, berdasarkan hasil observasi dan wawancara yang dilakukan, Kapal KM Sabuk Nusantara 66 memiliki kualitas yang baik dan sudah sesuai sebagai sarana transportasi wisata. Berdasarkan empat elemen yang diobservasi, fasilitas dan layanan wisata baik. Hanya saja, terkait dengan metode pemesanan dan akses informasi perlu dikembangkan sesuai dengan perkembangan teknologi digital. Selain itu, transportasi ini juga mendorong mobilitas penduduk, serta mensejahterakan perekonomian, dan mempermudah atau membuka jalur perdagangan.

\section{Profi dan Karakteristik Berwisata Wisatawan Pengguna KM Sabuk Nusantara 66}

\section{Profil Wisatawan}

Berdasarkan hasil survey profil wisatawan 66 pada Tabel 2, dari total 100 wisatawan yang menggunakan Kapal KM Sabuk Nusantara didominasi oleh wisatawan yang berjenis kelamin perempuan yaitu $65 \%, 92 \%$ di antaranya masih berstatus single atau belum menikah, karena mayoritas masih usia muda yaitu berusia 20-29 tahun sebanyak $81 \%$ dan 30-39 tahun sebanyak $12 \%$.

Tabel 2. Profil Wisatawan

\begin{tabular}{|c|c|c|c|}
\hline No & Profil Wisatawan & Pilihan & Persentase (\%) \\
\hline \multirow[t]{2}{*}{1} & Jenis Kelamin & Laki-laki & 35 \\
\hline & & Perempuan & 65 \\
\hline \multirow[t]{2}{*}{2} & Status Perkawinan & Single & 92 \\
\hline & & Menikah & 8 \\
\hline \multirow[t]{5}{*}{3} & Usia & $<20$ tahun & 5 \\
\hline & & 20-29 tahun & 81 \\
\hline & & 30-39 tahun & 12 \\
\hline & & 40-49 tahun & 1 \\
\hline & & $>49$ tahun & 1 \\
\hline \multirow[t]{7}{*}{4} & Domisili & Jakarta Utara & 5 \\
\hline & & Jakarta Pusat & 27 \\
\hline & & Jakarta Barat & 5 \\
\hline & & Jakarta Timur & 19 \\
\hline & & Jakarta Selatan & 11 \\
\hline & & Luar DKI Jakarta & 32 \\
\hline & & Luar Negeri & 1 \\
\hline \multirow[t]{3}{*}{5} & Tingkat Pendidikan & SMA & 35 \\
\hline & & D3 & 10 \\
\hline & & $\mathrm{D} 4 / \mathrm{S} 1$ & 55 \\
\hline \multirow[t]{7}{*}{6} & Pekerjaan & Mahasiswa & 58 \\
\hline & & Pegawai Swasta & 30 \\
\hline & & Wiraswasta & 3 \\
\hline & & PNS/TNI & 2 \\
\hline & & Ibu Rumah Tangga & 3 \\
\hline & & Pelajar & 1 \\
\hline & & Tidak bekerja & 3 \\
\hline \multirow[t]{5}{*}{7} & Pendapatan/bulan & $>$ Rp. $500.000,-$ & 4 \\
\hline & & Rp 500.000,-- Rp 1.000.000,- & 29 \\
\hline & & Rp 1.000.000 - Rp 3.000.000,- & 27 \\
\hline & & Rp 3.000.000,- - Rp 5.000.000,- & 22 \\
\hline & & $>\operatorname{Rp} 5.000 .000,-$ & 18 \\
\hline
\end{tabular}

Sumber: data diolah, 2020

Adapun domisili wisatawan paling banyak berasal dari wilayah DKI Jakarta sendiri, didominasi wisatawan yang berdomosili di Jakarta Pusat dan Jakarta
Timur. Wisatawan yang berasal dari luar DKI Jakarta juga cukup banyak yaitu mencapai $32 \%$, sedangkan yang berasal dari luar negeri hanya $1 \%$. Berdasarkan 
tingkat pendidikan, paling banyak berpendidikan D4/S1 sebanyak 55\%, di posisi kedua berpendidikan SMA, dan D3 diposisi terakhir sebanyak $10 \%$. Sementara itu, berdasarkan jenis pekerjaan, 58\% diantaranya masih berstatus mahasiswa, $30 \%$ bekerja sebagai pegawai swasta, sisanya pekerjaan lain paling banyak 3\% dari total wisatawan. Jika dilihat dari jumlah pendapatan, mayoritas sebanyak $29 \%$ masih tergolong rendah, yaitu diantara Rp 500.000-Rp 1.000.000,-. Kemudian sebanyak $27 \%$ berpendapatan Rp 1.000.000-Rp 3.000.000, hanya $18 \%$ yang berpendapatan > Rp. 5.000.000.
Adapun bila dilihat dari karakteristik berwisata wisatawan pada Tabel 3, mayoritas wisatawan sebanyak $56 \%$.baru satu kali melakukan kunjungan ke Kepulauan Seribu. Kemudian, 23\% diantaranya telah berkunjung dua kali dan 9\% telah berkunjung lebih dari 5 kali. Menariknya, sumber informasi rujukan yang paling banyak digunakan oleh wisatawan terkait penggunaan Kapal KM Sabuk Nusantara 66 adalah kerabat atau teman dekat sebanyak $48 \%$. Selanjutnya,sumber informasi kedua yang paling banyak digunakan adalah website/blog, dan ketiga, menggunakan Instagram sebanyak $12 \%$.

\section{Karakteristik Berwisata Wisatawan}

Tabel 3. Karakteristik Berwisata Wisatawan

\begin{tabular}{|c|c|c|c|}
\hline No & Karakteristik Berwisata & 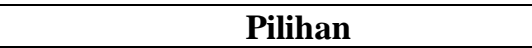 & Persentase $(\%)$ \\
\hline \multirow[t]{5}{*}{1} & Frekuensi Kunjungan & 1 kali & 56 \\
\hline & & 2 kali & 23 \\
\hline & & 3 kali & 9 \\
\hline & & 4 kali & 3 \\
\hline & & $>5$ kali & 9 \\
\hline \multirow[t]{8}{*}{2} & Sumber Informasi & $\mathrm{TV}$ & 12 \\
\hline & Penggunaan Kapal & & \\
\hline & & Facebook & 3 \\
\hline & & Twitter & 2 \\
\hline & & Instagram & 12 \\
\hline & & Website/Blog & 21 \\
\hline & & Kerabat & 48 \\
\hline & & Path & 2 \\
\hline \multirow[t]{5}{*}{3} & Teman Seperjalanan & Sendiri & 2 \\
\hline & & Pasangan & 2 \\
\hline & & Teman & 63 \\
\hline & & Keluarga & 17 \\
\hline & & Grup Wisata & 7 \\
\hline \multirow[t]{3}{*}{4} & Pulau Tujuan & Pulau Untung Jawa & 41 \\
\hline & & Pulau Pramuka & 44 \\
\hline & & Pulau Kelapa & 15 \\
\hline \multirow[t]{2}{*}{5} & Penggunaan Jasa Tour \& Travel & Menggunakan & 36 \\
\hline & & Tidak Menggunakan & 64 \\
\hline \multirow[t]{6}{*}{6} & Jenis $\quad$ Transportasi & Kereta Api & 7 \\
\hline & Pelabuhan & & \\
\hline & & Ojek & 13 \\
\hline & & Transjakarta & 9 \\
\hline & & Pribadi & 51 \\
\hline & & Angkutan Umum & 20 \\
\hline \multirow[t]{5}{*}{7} & Motivasi Perjalanan & Menghilangkan kejenuhan & 63 \\
\hline & & Melihat kehidupan masyarakat lokal & 1 \\
\hline & & Meningkatkan status & 1 \\
\hline & & Mendatangi pameran/festival & 1 \\
\hline & & Bersenang-senang & 34 \\
\hline \multirow[t]{3}{*}{8} & Tujuan utama menggunakan Kapal & Berwisata & 95 \\
\hline & & Berbisnis & 3 \\
\hline & & Mobilitas & 2 \\
\hline
\end{tabular}

Sumber: data diolah, 2020 
Sementara itu, teman seperjalanan yang mereka pilih untuk berwisata bersama paling banyak adalah teman sebesar $63 \%$ dan keluarga sebesar $17 \%$. Pulau yang paling banyak dituju wisatawan adalah Pulau Pramuka sebesar 44\%, Pulau Untung Jawa $41 \%$, dan yang terakhir Pulau Kelapa sebesar 15\%. Kebanyakan dari wisatawan melakukan perjalanan sendiri sebanyak $64 \%$, hanya $36 \%$ wisatawan yang menggunakan Tour dan Travel untuk mengelola perjalanannya. Untuk menuju Pelabuhan Sunda Kelapa, dapat diakses melalui beberapa moda transportasi. Namun, kebanyakan wisatawan menggunakan kendaraan pribadi yaitu sebanyak $51 \%$, jika dibandingkan dengan angkutan umum yang hanya sebesar $20 \%$, ojek $13 \%$, dan jenis transportasi lainnya.

Jika dilihat dari jumlah penumpang kapal KM Sabuk Nusantara 66 berdasarkan motivasi utama melakukan perjalanan ke Kepulauan Seribu, paling banyak sebesar $63 \%$ bertujuan untuk menghilangkan rasa jenuh, 34\% bersenang-senang. Namun, terdapat motivasi lain meski jumlahnya sedikit, yaitu $1 \%$ untuk melihat kehidupan masyarakat lokal, $1 \%$ untuk meningkatkan status, dan $1 \%$ mengunjungi festival/pameran. Sehingga, $\quad 95 \%$ diantaranya, memiliki tujuan utama untuk berwisata dan sisanya berbisnis dan sebagai sarana transportasi.

\section{Persepsi Wisatawan terhadap Kapal KM Sabuk Nusantara 66}

Berdasarkan data hasil kuisioner terkait dengan persepsi wisatawan terhadap Kapal KM Nusantara 66 pada Tabel 3, ratarata dari semua indikator faktor transportasi yang mempengaruhi keterjangkauan tujuan wisata dinilai baik. Mayoritas responden setuju-sangat setuju terkait dengan pernyataan dalam kuisioner terkait dengan penilaian faktor transportasi. Namun, pada pernyataan terkait dengan akses informasi tentang kapal KM Sabuk Nusantara 66 di website dan blog masih dinilai sangat kurang. Sebanyak $60 \%$ responden sangat tidak setuju dengan pernyataan mudahnya aksesbilitas informasi terkait jadwal keberangkatan dan metode pembelian tiket pada website atau blog.

Tabel 4. Rata-rata hasil jawaban persepsi wisatawan terhadap Kapal KM Sabuk Nusantara 66

\begin{tabular}{|c|c|c|c|c|c|}
\hline \multirow[t]{2}{*}{ No } & \multirow[t]{2}{*}{ Item Pernyataan } & \multicolumn{4}{|c|}{ Jawaban (\%) } \\
\hline & & Sangat setuju & Setuju & Tidak setuju & $\begin{array}{l}\text { Sangat tidak } \\
\text { setuju }\end{array}$ \\
\hline 1. & Kualitas moda transportasi & 37,5 & 53 & 9 & 0,5 \\
\hline 2. & $\begin{array}{l}\text { Konektivitas jaringan } \\
\text { transportasi }\end{array}$ & 34,6 & 61,6 & 3,4 & 0,4 \\
\hline 3. & $\begin{array}{l}\text { Biaya perjalanan atau } \\
\text { keterjangkauan }\end{array}$ & 57 & 30 & 1 & 12 \\
\hline 4. & Mobilitas & 52,5 & 34,25 & 8,25 & 5 \\
\hline 5. & Integrasi link dan mode & 24 & 68 & 8 & 0 \\
\hline 6. & $\begin{array}{l}\text { Permintaan } \\
\text { transportasi }\end{array}$ & 31 & 65 & 4 & 0 \\
\hline 7. & $\begin{array}{l}\text { Penggunaan ketersediaan } \\
\text { informasi }\end{array}$ & 26,2 & 52,6 & 8,6 & 12,6 \\
\hline 8. & Manajemen transportasi & 19,5 & 40,5 & 9,5 & 30,5 \\
\hline 9. & $\begin{array}{l}\text { Prioritas perjalanan dalam } \\
\text { kasus tertentu }\end{array}$ & 24,25 & 68,75 & 6,5 & 0,75 \\
\hline 10. & $\begin{array}{l}\text { Nilai atau manfaat } \\
\text { Rata-Rata }\end{array}$ & $\begin{array}{c}21 \\
32,8\end{array}$ & $\begin{array}{c}77 \\
55,07\end{array}$ & $\begin{array}{c}2 \\
6,03\end{array}$ & $\begin{array}{c}0 \\
6,2\end{array}$ \\
\hline
\end{tabular}

Sumber: data diolah, 2020 
Berdasarkan data hasil penelitian, Kapal KM Sabuk Nusantara 66 sudah memenuhi empat elemen transportasi Benson \& Whitehead (2000). Dari segi moda transportasi sudah memiliki kapasitas dan fasilitas yang cukup, kondisi juga dalam keadaan baik, pengecekan kondisi dilakukan berkala, serta dilengkapi dengan alat keselamatan yang memadai. Begitupun dari segi jalan dan terminal. Hanya saja, terkait dengan terminal perlu ditingkatakan sarana pendukung tempat makan yang lebih baik sehingga dapat meningkatkan kenyamanan bagi wisatawan yang akan berkunjung ke Kepulauan Seribu. Terkait dengan elemen teknologi, memang PT Pelni telah menyediakan informasi terkait dengan kapal pada Website dan Blog, namun sayangnya jadwal dan rute serta metode pemesanan belum diinformasikan secara detail. Penggunaan media digital lainnya juga perlu dioptimalisasikan, terutama media sosial. Pada era digital ini, hampir semua informasi pada semua tahap perjalanan wisata dilakukan melalui internet. Misalnya, pemesanan online transportasi pada situs mobile booking seperti traveloka (Muliana et al., 2016), pemilihan destinasi (Damanik et al., 2019), akomodasi (Wachyuni et al., 2018; Wachyuni \& Wiweka, 2020). Akses informasi dan pemesanan ini dapat memudahkan wisatawan untuk melakukan perjalanan wisata dan diharapkan dapat meningkatkan motivasi berkunjung ke destinasi. Apalagi jika dilihat dari hasil profil wisatawan, mayoritas merupakan wisatawan milenial (berusia 20-39 tahun) seluruh aktifitasnya tidak terlepas dari teknologi digital (Wiweka, Wachyuni, Rini, et al., 2019). Menurut studi yang dilakukan oleh (Strauss \& Howe, 2000), milenial adalah mereka yang lahir pada tahun 1982-2000, sedangkan (Martin \& Tulgan, 2002) menyatakan milenial lahir pada tahun 19782000.

Terkait dengan karakteristik berwisata mereka, informasi tentang Kapal KM Sabuk Nusantara 66 paling banyak didapat melalui kerabat. Hal ini dikarenakan informasi yang disediakan PT Pelni masih sangat kurang, hanya disediakan di website. Jika optimalisasi penggunaan media sosial ditingkatkan, optimis kunjungan ke Kepulauan Seribu akan meningkat. Dari Tabel 3, dilihat mayoritas wisatawan baru satu kali melakukan kunjungan, terlihat sedikit sekali yang melakukan kunjungan kembali. Hal ini perlu diperhatikan pengelola destinasi Kepulauan Seribu untuk berkoordinasi dalam peningkatan aksesbilitas. Dengan fasilitas yang baik dan memadai, Kapal KM Sabuk Nusantara 66 dapat dimaksimalkan sebagai sarana transportasi wisata.

Adapun persepsi wisatawan terkait kapal KM Sabuk Nusantara 66 secara umum tergolong baik. Pada aspek moda transportasi, wisatawan mempersepsikan kapal nyaman digunakan dan sangat menikmati perjalanan wisata. Fasilitas sangat baik dan lengkap dan bongkar muat barang tidak mengganggu naik turun penumpang karena terdapat pintu khusus untuk penumpang. Wisatawan juga merasa aman karena alat keamanan dan dilengkapi dengan asuransi jiwa. Akses menuju pelabuhan juga dipersepsikan baik karena mudah terknoneksi dengan kendaraan umum, termasuk adanya transportasi gratis yang disediakan yaitu Transjakarta. Jarak antar pulau juga cukup dekat sehingga wisatawan mudah untuk berganti destinasi menggunakan Kapal KM Sabuk Nusantara 66 ini. Kualitas yang baik ini harus dipertahankan, karena secara telah dibuktikan bahwa kualitas layanan transportasi dapat berpengaruh terhadap loyalitas pengguna (Wachyuni, 2019).

Biaya perjalanan juga tergolong murah jika disesuaikan dengan profil wisatawan yang rata-rata masih kuliah dan belum berpendapatan besar. Kecepatan kapal juga lebih baik dari kapal tradisional karena hanya dengan 4 jam dapat menempuh 3 pulau (Untung Jawa, Pramuka, Kelapa). Selain jadwal dipersepsikan efisien dan tepat 
waktu, kendaraan pribadi penumpang juga dapat dimuat secara aman di dalam kapal. Adanya Kapal KM Sabuk Nusantara 66 dianggap sangat memudahkan wisatawan menuju destinasi. Wisatawan setuju bahwa mereka akan menggunakan kembali kapal ini untuk transportasi mereka ke Kepulauan Seribu bahkan akan merekomendasikannya kepada kerabat. Kapal juga sangat ramah disabilitas karena pada memberikan prioritas pada difabel, ibu hamil, lansia, dan orang sakit. Hanya, terdapat hal yang perlu ditingkatkan yaitu akses informasi online dan sistem pemesanan online. Karena, berdasarkan hasil survey, mayoritas wisatawan beranggapan pembelian tiket secara online dianggap lebih efisien waktu dan tenaga.

\section{KESIMPULAN}

Kesimpulan dari penelitian ini bahwa Kapal KM Sabuk Nusantara sangat layak dijadikan sarana transportasi wisata untuk menuju Kepulauan Seribu. Profil wisatawan didominasi oleh generasi milenial yang cenderung menggunakan teknologi dalam semua aktifitasnya sehingga perlu dilakukan penyesuaian dan penggunaan media digital dalam penyediaan informasi dan pemesanan. Kelayakan Kapal KM Sabuk Nusantara 66 ini sesuai dengan persepsi wisatawan terkait 10 indikator faktor transportasi untuk penunjang pariwisata. Penelitian ini memberikan implikasi praktis dimana dapat digunakan sebagai saran pengembangan operator Kapal dalam hal ini PT Pelni serta pengelola destinasi untuk terus meningkatkan kualitas pelayanan sehingga dapat meningkatkan minat berkunjung wisatawan ke Kepulauan Seribu. Limitasi penelitian ini hannya membahas persepsi wisatawan terkait faktor transportasi, lebih lanjut perlu dianalisis bagaimana kualitas pelayanan dan kepuasan wisatawan dalam menggunakan kapal KM Sabuk Nusantara 66. Karena, menurut Wachyuni (2019), kualitas layanan dan kepuasan berpengaruh kepada loyalitas wisatawan menggunakan transportasi. Loyalitas ini akan mempengaruhi penggunaan kembali dan rekomendasi kepada orang lain untuk menggunakan sarana transportasi tersebut.

\section{SARAN}

Berdasarkan temuan penelitian, kajian ini menawarkan beberapa saran atau rekomendasi, diantaranya perlu adanya komunikasi yang baik antara pihak pengelola pelabuhan (PT. pelindo II) dan pengelola kapal KM Sabuk Nusantara 66 (PT. Pelni) sehingga dapat bekerja sama dalam memaksimalkan fasilitas seperti ruang tunggu penumpang di dalam pelabuhan, sehingga penumpang dapat terhindar dari aktivitas bongkar muat kapal-kapal barang. Selain itu, dimasa depan diharapkan sudah tersedia sistem reservasi berbasis online untuk mengecek rute perjalanan, jadwal keberangkatan, dan mengecek ketersediaan kursi, hingga reservasi dan penyesuaian jadwal, mengingat saat ini makin berkembangnya perkembangan teknologi yang membuat segalanya menjadi efisien. Stakeholder juga dianggap perlu meningkatkan strategi promosi di sosial media, menggunakan website, blog, maupun Instagram.

\section{DAFTAR PUSTAKA}

Arcana, K. T. P., \& Wiweka, K. (2015). The Impact of Managing Sustainable Event and the Contribution to the Formation of Destination Image at Nusa Dua Resort, Bali. Jurnal Ilmiah Hospitality Management, 6(1), 43-48.

BPS. (2020). Kepulauan Seribu dalam angka.

https://kepulauanseribukab.bps.go.id/p ublikasi.html

Buhalis, D. (2000). Marketing the competitive destination of the future. Tourism Management, 21(1), 97-116. 
Cohen, E. (1972). Toward a sociology of international tourism. Social Research, 164-182.

Cooper, C. (2008). Tourism: Principles and practice. Pearson education.

Damanik, D., Wachyuni, S. S., Wiweka, K., \& Setiawan, A. (2019). The Influence of Social Media on the Domestic Tourist's Travel Motivation Case Study: Kota Tua Jakarta, Indonesia. Current Journal of Applied Science and Technology, 1-14. https://doi.org/10.9734/cjast/2019/v36i 630263

dephub.go.id.

(2020).

Kantor

Kesyahbandaran dan Otoritas

Pelabuhan Kelas III Sunda KelapaProfil.

http://dephub.go.id/org/ksopsundakela $\mathrm{pa} / \mathrm{profil}$

Duhamel, P. (2018). Géographie du tourisme et des loisirs: Dynamiques, acteurs, territoires. Armand Colin.

Imboden, D. (2020). Venice Water Buses. https://europeforvisitors.com/venice/art icles/venice-vaporetto-water-buses.htm

Ismayanti. (2010). Pengantar Pariwisata. https://pdf.wecabrio.com/pengantarpariwisata-ismayanti.pdf

jakarta-tourism.go.id. (2020). Website Wisata Kepulauan Seribu Diluncurkan-Dinas Pariwisata \#VisitJakarta. https://jakartatourism.go.id/visit/blog/2016/08/websit e-wisata-kepulauan-seribu-diluncurkan

Kompas. (2018). KM Sinar Bangun Disebut Tenggelam Satu Mil dari Pelabuhan Tigaras. https://regional.kompas.com/read/2018 /06/20/13071721/km-sinar-bangundisebut-tenggelam-satu-mil-daripelabuhan-tigaras

Kotler, P., Wong, V., Saunders, J., \& Armstrong, G. (2007). Moderní marketing. Grada publishing as.

Kusmayadi, Wiweka, K., Parantika, A., Wahyuni, N., \& Adnyana, P. P. (2019). A Time Series Analysis of Airline
Pricing Behavior Case Study Jakarta (CGK)_Denpasar (DPS) Market. Journal of Economics, Management and Trade, 1-10. https://doi.org/10.9734/jemt/2019/v22i 630105

Leiper, N. (1979). The framework of tourism: Towards a definition of tourism, tourist, and the tourist industry. Annals of Tourism Research, 6(4), 390-407.

Martin, C. A., \& Tulgan, B. (2002). Managing the generation mix: From collision to collaboration. Human Resource Development.

McIntosh, R. W., Goeldner, C. R., \& Ritchie, J. B. (1995). Tourism: Principles, practices, philosophies. John Wiley and Sons.

Mohamed, A. R. (2019). Multi-Cultural Communication is Essential for Tourism Industry: Global to Local Perspective: Business \& Management Book Chapter | IGI Global. https://www.igiglobal.com/chapter/multi-culturalcommunication-is-essential-fortourism-industry/210384

Muliana, E., Negara, I. M. K., \& Dewi, L. G. L. K. (2016). Analisis Faktor-Faktor Yang Mendorong Wisatawan Melakukan Keputusan Pembelian Tiket Pesawat Melalui Mobile Booking Pada Situs Traveloka. Com. Jurnal IPTA ISSN, 2338, 8633.

Myswissalps. (2020). Overview of the Swiss Travel System passes in 2020. https://www.myswissalps.com/forum/t opic/overview-of-the-swiss-travelsystem-passes-in-2020

Nyoman, P. (2002). Ilmu pariwisata: Sebuah pengantar perdana / oleh Nyoman S. Pendit | OPAC Perpustakaan Nasional RI.

https://opac.perpusnas.go.id/DetailOpa c. $\operatorname{aspx}$ ?id=530492

Seribu, A. P. (2020). Pesona Keindahan Pulau Seribu. https://pulau- 
seribu.com/pesona-keindahan-pulauseribu/

Setiawan, B., Trisdyani, N. L. P., Adnyana, P. P., Adnyana, I. N., Wiweka, K., \& Wulandani, H. R. (2018). The Profile and Behaviour of 'Digital Tourists' When Making Decisions Concerning Travelling Case Study: Generation Z in South Jakarta. Advances in Research, $1-13$. https://doi.org/10.9734/AIR/2018/4387 2

Simanjuntak, B. A., Tanjung, F., \& Nasution, R. (2017). Sejarah pariwisata: Menuju perkembangan pariwisata Indonesia. Yayasan Pustaka Obor Indonesia.

Siregar, M. (2012). Beberapa masalah ekonomi dan manajemen transportasi. Lembaga Penerbit, Fakultas Ekonomi, Universitas Indonesia.

Spillane, J. J. (1991). Ekonomi pariwisata: Sejarah dan prosepeknya. Kanisius.

Strauss, W., \& Howe, N. (2000). Millennials rising: The next great generation. Vintage Books New York.

Sugiono. (2010). Sugiyono. (2010). Metode Penelitian Kuantitatif Kualitatif \& RND. Alfabeta, Bandung. Sujarweni, V. Wiratna. (2015). SPSS Untuk Penelitian-PDF Free Download. https://adoc.tips/sugiyono-2010metode-penelitian-kuantitatifkualitatif-rnd-a.html

Sunjayadi, A. (2017). Dari Vreemdelingenverkeer ke toeristenverkeer: Dinamika pariwisata di Hindia Belanda 1891-1942= From Vreemdelingenverkeer to toeristenverkeer tourism dynamics in the dutch East Indies 1891-1942.

Tribe, J. (2009). Philosophical issues in tourism. Channel view publications.

Van Truong, N., \& Shimizu, T. (2017). The effect of transportation on tourism promotion: Literature review on application of the Computable General Equilibrium (CGE) Model.
Transportation Research Procedia, 25, 3096-3115.

Visitlondon, V. to the. (2020). London Underground. Visitlondon.Com. https://www.visitlondon.com/travellerinformation/getting-aroundlondon/london-tube

Voaindonesia.com. (2018). Kapal Tenggelam di Makassar, Sedikitnya 13 Tewas.

https://www.voaindonesia.com/a/kapal -tenggelam-di-makassar-sedikitnya-13tewas/4436819.html

Wachyuni, S. S. (2019). The Effects of Service Quality, Customer Perceived Value, and Customer Satisfaction Towards Customer Loyalty of DAMRI Tour Bus. Journal of Business on Hospitality and Tourism, 5(2), 129142.

Wachyuni, S. S., \& Wiweka, K. (2020). Kepuasan Wisatawan dalam Penggunaan E-Commerce Agoda dalam Pemesanan Hotel. Journal of Tourism Destination and Attraction, 8(1), 61-70.

Wachyuni, S. S., Wiweka, K., \& Liman, M. (2018). Pengaruh Online Distribution Channels (Ods) Terhadap Hotel Revenue. Journal of Tourism and Economic, 1(2), Article 2. https://doi.org/10.36594/jtec.v1i2.29

Wakefield, J. (2020). Dubai tests drone taxi service-BBC News. BBC. https://www.bbc.com/news/technology $-41399406$

Wiweka, K., \& Arcana, K. T. P. (2019). Rethinking the Theory of Tourism: What is Tourism System in Theoretical and Empirical Perspective? Journal of Business on Hospitality and Tourism, 5(2), 318-336.

Wiweka, K., Wachyuni, S. S., Rini, N. A., Adnyana, I. N., \& Adnyana, P. P. (2019). PERILAKU BERWISATA WISATAWAN GENERASI MILENIAL DI JAKARTA PADA 
ERA REVOLUSI INDUSTRI 4.0.

Science,

$1-12$. 4(3), 22.

https://doi.org/10.9734/jesbs/2019/v30i

Wiweka, K., Wachyuni, S. S., Simawang, S. 230124

P., Adnyana, P., \& Wihartaty, E. www.bateaux-mouches.fr/en. (2020). Paris (2019). Current Issues of Backpacking Seine river cruise | lunch \& dinner Tourism Development: Profile and Characteristics of "Sharecost" and "Opentrip" Tourist. Journal of cruise | Bateaux Mouches ${ }^{\circledR}$ Official Website. https://www.bateauxEducation, Society and Behavioural mouches.fr/en 